SOSIOLIUM

\title{
EFEKTIVITAS PEMBELAJARAN IPS MENGGUNAKAN VIDEO ANIMASI DAN KAHOOT! MATERI INTERAKSI ANTARNEGARA- NEGARA ASEAN PADA SISWA KELAS VIII SMP N 3 TEBO JAMBI
}

\author{
Rahmawati Pratiwi, Fredy Hermanto ${ }^{\bowtie}$ \\ Prodi Pendidikan IPS, Fakultas Ilmu Sosial, Universitas Negeri Semarang, Indonesia
}

\section{Info Artikel \\ Sejarah Artikel: \\ Disubmit: Juli 2021 \\ Direvisi: Agustus 2021 \\ Diterima: September \\ 2021}

\section{Keywords:}

Effectiveness, Kahoot!,

Social Science Learning,

Animation Video

\begin{abstract}
Sari
Hasil belajar siswa masih belum baik, siswa mengalami hambatan dan kesulitan dalam memahami materi khususnya materi tentang ASEAN. Peneliti memberikan media pembelajaran video animasi dan kahoot! dalam pembelajaran IPS. Metode yang digunakan dalam penelitian ini yaitu kuantitatif. Desain yang dipakai dalam penelitian ini adalah quasi experimental/eksperimen semu dengan jenis nonequivalent control group design. Hasil dari penelitian ini yaitu media kahoot! dan video animasi efektif diterapkan. Hal tersebut dibuktikan empat indicator efektivitas yaitu (1) kemampuan guru dalam mengelola pembelajaran masuk kategori sangat tinggi dengan nilai di kelas eksperimen 73 dan kelas control 66, (2) aktivitas belajar peserta didik dalam pembelajaran menunjukkan rata-rata sangat aktif dengan skor di kelas eksperimen 92,86 sedangkan kelas kontrol 62,50, (3) peningkatan hasil belajar kelas ekperimen dari 46,4 menjadi 84,4, sedangkan kelas kontrol dari 46,0 menjadi 78,6, (4) respon peserta didik terhadap pembelajaran yang diterapkan guru masuk kategori sangat tinggi dengan skor di kelas eksperimen 75 dan kelas kontrol 68,7.
\end{abstract}




\section{PENDAHULUAN}

Pendidikan merupakan hal yang sangat penting bagi manusia dan sebagai investasi yang paling utama bagi bangsa, melalui pendidikan manusia memperoleh imu pengetahuan yang dapat bermanfaat dalam kehidupan. Berdasarkan UU Nomor 20 Tahun 2003 tentang Sistem Pendidikan Nasional, menjelaskan bahwa pendidikan adalah usaha sadar dan terencana untuk mewujudkan suasana belajar dan proses pembelajaran agar peserta didik secara aktif mengembangkan potensi dirinya untuk memiliki kekuatan spiritual keagamaan, pengendalian diri, kepribadian, kecerdasan, akhlak mulia, serta keterampilan yang diperlukan dirinya, masyarakat, bangsa dan negara. Munib (2010:29) menyatakan bahwa pendidikan mengemban tugas untuk menghasilkan generasi yang baik, manusia-manusia yang lebih berkebudayaan, manusia sebagai individu yang memiliki kepribadian yang lebih baik.

IPS adalah salah satu bidang studi yang dipelajari oleh siswa SMP. Bidang studi IPS mencakup kepada ilmu-ilmu sosial yang ditujukan untuk merangsang kemampuan berpikir siswa. Menurut Effendi dalam Karmila (2013:10) yang menyebutkan bahwa, "IPS ialah nama bidang studi yang merupakan integrasi konsep ilmu-ilmu sosial, humaniora, sains, isu, masalah sosial kehidupan dimensi pedagogik dan psikologis sesuai karakteristik kemampuan berpikir peserta didik holistik". Pada hakikatnya, guru merupakan komponen utama dalam kegiatan pembelajaran. Syaodih dalam Mulyasa (2009:13) menyatakan bahwa guru memegang peranan yang cukup penting baik dalam perencanaan maupun pelaksanaan kurikulum. Tantangan khusus bagi guru di masa kini ialah bagaimana menciptakan pembelajaran yang menggairahkan, menantang nafsu siswa dan menyenangkan.

Berdasarkan hasil wawancara dengan Ibu Rubiyem selaku guru mata pelajaran IPS di SMP N 3 Tebo terdapat kendala dalam proses pembelajaran IPS, diantaranya adalah masih kurangnya ketersediaan media pembelajaran, hanya terdapat media peta dan globe yang ketersediaannya masih sangat terbatas dan media ini hanya bisa diterapakan pada materi peta saja. Observasi awal di kelas VIII guru menyampaikan materi tentang mengenal negara-negara ASEAN. Dari hasil observasi tersebut siswa belum memahami materi dengan baik, dan banyak siswa yang tidak paham dengan materi yang dijelaskan. Selain itu, masih banyak siswa yang belum mencapai Kriteria Kemampuan Minimum (KKM). Mata pelajaran IPS memiliki KKM 75. Dari 191 siswa hanya 44 siswa yang berhasil mencapai KKM. Hal ini menunjukkan hasil belajar siswa belum baik karena banyak siswa yang mendapat nilai dibawah 75 .

Menurut Hamalik dalam Kustandi dan Sutjipto (2013:19) mengemukakan bahwa "pemakaian media pembelajaran dalam proses belajar mengajar dapat membangkitkan keinginan dan minat yang baru, membangkitkan motivasi dan rangsangan kegiatan belajar dan bahkan membawa pengaruh-pengaruh psikologi siswa". Video animasi dan kahoot! adalah salah satu media berbasis digital dan modern. Penggunaan media diharapkan dapat merubah cara belajar siswa sehingga hasil belajar siswa mendapat hasil yang baik, siswa lebih tertarik untuk mengikuti pembelajaran, dan minat untuk belajar meningkat.

Berdasarkan latar belakang tersebut, peneliti bermaksud untuk mengadakan penelitian yang berjudul " "Efektivitas pembelajaran IPS menggunakan media video animasi dan kahoot! materi interaksi antarnegara-negara ASEAN pada siswa kelas VIII SMP N 3 Tebo Jambi".

\section{METODE}

Populasi penelitian ini adalah seluruh siswa kelas VIII SMP N 3 Tebo, yang terbagi dalam 6 kelas, yaitu VIII A-F. Adapun kelas yang diambil sampel dipilih dengan pertimbangan kedua kelas tersebut memiliki rata-rata hasil belajar yang hampir sama. Kelas yang akan digunakan adalah VIII B sebagai kelas kontrol dan kelas VIII C sebagai kelas eksperimen. Metode eksperimen yang digunakan dalam penelitian ini adalah metode eksperimen semu (quasi experimental) yaitu eksperimen yang mempunyai kelompok kontrol, tetapi tidak dapat berfungsi sepenuhnya untuk mengontrol variabel-variabel luar yang mempengaruhi pelaksanaan eksperimen. Variabel bebas dalam penelitian ini adalah media pembelajaran video animasi dan kahoot!, sedangkan variabel terikat dalam penelitian ini adalah efektivitas pembelajaran IPS materi 
interaksi antar negara-negara ASEAN kelas VIII SMP N 3 Tebo Jambi.

Teknik pengumpulan data pada penelitian adalah tes dan kuisioner. Uji validitas yang digunakan pada penelitian ini yaitu uji validitas internal dan uji validitas eksternal. Cara mengetahui reliabilitas suatu instrument, ialah dengan melihat hasil perhitungan menggunakan rumus r11 kemudian dibandingkan dengan nilai $\mathrm{r}$ tabel. Interpretasi yang digunakan adalah semakin kecil indeks yang diperoleh, maka semakin sulit soal yang digunakan. Sebaliknya, semakin besar indeks yang diperoleh, semakin mudah soalnya. Daya beda dilakukan untuk membedakan siswa yang pandai dengan siswa yang berkemampuan rendah.

\section{HASIL DAN PEMBAHASAN}

1. Analisis Kemampuan Guru Mengelola Pembelajaran

a. Analisis Kemampuan Guru dalam Mengelola Pembelajaran di Kelas Eksperimen

Awal pembelajaran guru membuka pembelajaran dengan salam dan berdoa. Kemudian guru membahas materi pertemuan sebelumnya dan kaitannya dengan materi yang akan diajarkan, guru memberi motivasi dan tujuan pembelajaran, setelah itu guru bertanya kepada siswa tentang materi sebelumnya dan menunjuk siswa untuk menjawab. Guru ingin mengetahui apakah siswa masih ingat dengan materi sebelumnya atau tidak. Kemudian memberikan materi pelajaran tentang interaksi antarnegara-negara ASEAN. Pembelajaran yang akan diterapkan yaitu pembelajaran menggunakan model pembelajaran think, pair, share (TPS) dan menggunakan media kahoot!. Terlebih dahulu siswa akan dibagi menjadi 6 kelompok, dimana 1 kelompok terdiri dari 2-3 siswa. Pembagian kelompok dipilih oleh guru dan peneliti dengan pertimbangan siswa yang mempunyai handphone, karena karena tidak semua siswa mempunyai handphone. Setelah dibagi kelompok, guru akan menjelaskan materi mengenai interaksi antarnegara-negara ASEAN. Dalam menjelaskan materi, interaksi antar siswa dan guru juga terjalin dengan baik. Guru melakukan tanya jawab dan juga berdiskusi dengan siswa dan menerapkan model pembelajaran TPS. Siswa berfikir dan berpasangan dengan siswa lain dan saling bekerja sama untuk menjawab pertanyaan yang diberikan oleh guru dengan waktu yang sudah ditentukan. Setelah materi selesai dijelaskan, siswa memulai kegiatan pembelajaran dengan menggunakan media kahoot!. Siswa akan menjawab pertanyaan-pertanyaan yang telah disediakan oleh guru dan peneliti dengan waktu yang sudah ditentukan. Siswa yang dapat menjawab secara benar dan cepat akan mendapat nilai yang tinggi dan menang.

Guru dan peneliti bekerja sama memantau jalannya pembelajaran dengan menggunakan media kahoot! agar tetap kondusif. Setelah semua siswa sudah menjawab semua pertanyaan akan terlihat siapa pemenangnya dan nilai akan muncul secara sistematis. Diakhir pelajaran guru memberikan tanya jawab dan kemudian bersama-sama dengan siswa menyimpulkan tentang materi yang telah dipelajari pada saat itu.

Berdasarkan penilaian dari guru IPS kelas VII yaitu Ibu Komariyah, hasil penjabaranya adalah sebagai berikut: indikator pertama yaitu kegiatan pendahuluan mendapatkan skor 21. Indikator kedua adalah kegiatan inti mendapatkan skor 41 . Indikator ketiga yaitu kegiatan penutup mendapatkan skor 8 .

Berdasarkan penjumlahan dari ketiga indikator didapatkan hasil akhir atau skor total 73 skor, penilaian mulai dari kelengkapan perangkat pembelajaran yang sesuai tidaknya dengan apa yang disampaikan sampai dengan bagaimana guru menyampaikan pembelajaran di dalam kelas. Sehingga dapat disimpulkan bahwa pengelolaan guru dalam proses pembelajaran IPS dengan media pembelajaran dikatakan sangat baik atau sangat tinggi.

\section{b. Analisis Kemampuan Guru dalam Mengelola Pembelajaran di Kelas Kontrol Pembelajaran di kelas kontrol} menggunakan media pembelajaran video animasi dan model pembelajaran TPS. Hampir sama dengan kelas eksperimen, pembelajaran dimulai dengan salam dan berdoa. Selanjutnya guru memberi motivasi dan tujuan pembelajaran. Kemudian guru membahas materi pertemuan sebelumnya untuk mengingat kembali materi yang sudah diajarkan dengan menampilkan video animasi. Selanjutnya siswa akan dibagi menjadi 8 kelompok yang masingmasing kelompok terdiri dari 2 siswa yang nantinya akan menjawab/menyimpulkan pembelajaran yang telah guru sampaikan. Kelompok yang berani menyimpulkan pertama 
akan menjadi pemenang dan mendapat nilai. Setelah dibagi kelompok, guru menjelaskan materi dengan menayangkan video animasi berisikan materi interaksi antarnegara-negara ASEAN. Disela menjelaskan materi, guru menerapkan model pembelajaran TPS dimana siswa diberi pertanyaan oleh guru mengenai materi yang berhubungan dengan materi interaksi antarnegara-negara ASEAN, lalu siswa berfikir dan berpasangan dengan kelompok yang sudah ditentukan. Kemudian masing-masing kelompok akan bekerjasama mencari jawaban. Setelah mencari jawaban, masing-masing kelompok akan membagikan hasil pemikiran dengan kelompoknya. Setelah materi dijelaskan dan video animasi sudah ditayangkan, siswa dipersilahkan menyimpulkan pembelajaran yang telah selesai dijelaskan. Guru mempersilahkan 3 kelompok menyimpulkan materi. Diakhir pelajaran guru bersama-sama dengan siswa menyimpulkan tentang materi yang telah dipelajari pada saat itu.

Berdasarkan penilaian dari guru IPS kelas IX yaitu Ibu Saniarti, hasil penjabaranya adalah sebagai berikut: indikator pertama yaitu kegiatan pendahuluan mendapatkan skor 19. Indikator kedua adalah kegiatan inti mendapatkan skor 41. Indikator ketiga yaitu kegiatan penutup mendapatkan skor 6 . Berdasarkan penjumlahan dari ketiga indikator didapatkan hasil akhir atau skor total 66 skor, penilaian mulai dari kelengkapan perangkat pembelajaran yang sesuai tidaknya dengan apa yang disampaikan sampai dengan bagaimana guru menyampaikan pembelajaran di dalam kelas. Sehingga dapat disimpulkan bahwa pengelolaan guru dalam proses pembelajaran IPS dengan media pembelajaran video animasi dikatakan sangat baik.

Berdasarkan kriteria diatas dapat disimpulkan bahwa kemampuan guru dalam mengelola pembelajaran IPS untuk kelas eksperimen mendapat kriteria sangat baik dengan jumlah poin 73 sedangkan untuk kelas kontrol mendapatkan jumlah pont 66 . Selisih antara kelas eksperimen dan kelas kontrol 8 poin. Sehingga kemampuan guru dalam mengelola pembelajaran IPS lebih efektif di kelas eksperimen (8C) dengan pembelajaran media pembelajaran kahoot!.

\section{Aktivitas Belajar Peserta Didik \\ a. Analisis Aktivitas Siswa di Kelas Eksperimen}

Awal pembelajaran dimulai, guru menyampaikan tujuan pembelajaran secara jelas, menumbuhkan sikap-sikap yang positif terhadap pelajaran. Selama pembelajaran berlangsung, aktivitas siswa sangat baik. Siswa memperhatikan guru dalam menjelaskan materi, siswa sangat antusias mengikuti pembelajaran, kondusif, komunikasi antar siswa dan guru terjalin dengan baik, dan siswa menanggapi pertanyaan yang diberikan oleh guru.

Proses kegiatan pembelajaran yang telah dilakukan dengan menggunakan media pembelajaran kahoot! peserta didik terlihat sangat antusias dalam mengikuti proses pembelajaran, karena merupakan hal yang baru dan belum pernah diterapkan sebelumnya. Pada saat awal pembelajaran, siswa tidak kondusif dikarenakan siswa masih bingung dan belum paham bagaimana menggunakannya. Setelah dijelaskan, siswa sangat antusias dan mengerti bagaimana menggunakannya.

Semua siswa bekerja sama dengan masingmasing kelompok dan fokus menjawab pertanyaan-pertanyaan dalam kahoot!. Semua siswa menyelesaikan permainan sampai selesai dan 7 kelompok menjawab pertanyaan dengan hasil yang tidak rendah. Tidak ada yang nilainya dibawah $50 \%$. Ini artinya siswa banyak yang memahami materi yang telah disampaikan dibuktikan dengan nilai yang telah didapat dari hasil kuis kahoot!. Hambatan-hambatan yang terjadi selama bermain kuis kahoot! yaitu masalah koneksi internet yang tidak stabil, karena siswa menggunakan provider yang berbeda-beda, wifi di sekolah juga tidak lancar, sehingga semua kelompok tidak menjawab dan menyelesaikan secara bersamaan. Siswa yang sudah menyelesaikan permainan harus menunggu kelompok lain yang belum menyelesaikan permainan. Namun hal ini tidak terlalu mengganggu jalannya pembelajaran, kelompok yang sudah menyelesaikan tetap kondusif dan kelompok yang belum menyelesaikan tetap fokus menjawab pertanyaan.

Berdasarkan hasil angket mengenai aktivitas siswa yang telah di isi menunjukkan aktivitas siswa kelas eksperimen tergolong sangat aktif. Hal ini terlihat dari 14 siswa, 1 orang aktif mengikuti pembelajaran IPS dengan presentase sebesar 7,14\%, dan 13 siswa dengan persentase $92,9 \%$ siswa sangat aktif mengikuti pembelajaran IPS yang disampaikan dengan media pembelajaran kahoot!.

\section{b. Analisis Aktivitas Siswa di Kelas Kontrol}

Penerapan pembelajaran menggunakan media video animasi pembelajaran dalam 
pembelajaran IPS di kelas VIII B lancar dikarenakan peserta didik sudah memahami tahapan-tahapan pembelajaran yang dijelaskan oleh guru. Guru menyampaikan tujuan pembelajaran secara jelas, menumbuhkan sikapsikap yang positif terhadap pelajaran. Awal pembelajaran aktivitas siswa dapat dikatakan kondusif dan siswa memperhatikan guru ketika menjelaskan.

Pelaksanaan treatment juga berjalan dengan baik dan lancar. Siswa dibagi menjadi 8 kelompok yang masing-masing terdiri dari 2 orang. saat pembagian kelompok, siswa tetap kondusif dan melaksanakan perintah guru. Siswa bekerjasama dengan teman satu kelompok, sebagian besar siswa memperhatikan video yang ditampilkan. Walaupun ada beberapa yang mengantuk, tetapi setelah saya beri arahan untuk fokus dan mencatat hal-hal penting dari tayangan video animasi, siswa kemudian dapat memperhatikan dengan fokus.

Kendala yang terjadi dari proses pembelajaran ini adalah suara dari luar ruangan yang tidak kondusif membuat suara dari video animasi yang ditampilkan tidak terdengar dengan jelas. Namun, kendala tersebut dapat diatasi sehingga pembelajaran dapat terlaksana dengan lancar. Siswa sangat aktif mencatat poin-poin yang dijelaskan dalam video. Setelah video selesai, guru mempersilahkan 3 kelompok yang berani menyimpulkan penjelasan dari video. Awalnya, hanya 1 kelompok yang berani menyimpulkan yaitu Tiara dan Nabila. Namun, setelah itu terdapat 2 kelompok yang tunjuk tangan. Pada akhir pembelajaran guru memberikan tanya jawab dan kemudian bersama-sama dengan siswa menyimpulkan tentang materi yang telah dipelajari pada saat itu.

Berdasarkan hasil angket mengenai aktivitas siswa yang telah di isi menunjukkan aktivitas siswa kelas kontrol tergolong aktif. Hal ini terlihat dari 16 siswa 6 siswa diantaranya aktif mengikuti pembelajaran dengan presentase sebesar 37,5\% dan 10 siswa lainnya dengan presentase sebesar $62,5 \%$ sangat aktif dalam mengikuti pembelajaran IPS yang disampaikan dengan menggunakan media video animasi.

Kegiatan pengamatan aktivitas peserta didik diperoleh hasil belajar peserta didik secara afektif dan psikomotorik, secara afektif hasil belajar didapatkan dari pengamatan aktivitas peserta didik dalam memperhatikan penjelasan materi dari guru, memperhatikan teman yang sedang berpendapat dan diskusi selama kegiatan pembelajaran. Secara psikomotorik dilihat dari pengamatan aktivitas peserta didik dalam bertanya, menjawab, diskusi, hingga presentasi di depan kelas.

Berdasarkan kriteria diatas dapat disimpulkan bahwa aktivitas peserta didik dalam pembelajaran IPS untuk kelas eksperimen mendapat kriteria sangat aktif dengan jumlah 92,9\% sedangkan untuk kelas kontrol mendapatkan jumlah $62,5 \%$. Sehingga aktivitas siswa dalam pembelajaran IPS lebih efektif di kelas eksperimen (8C) dengan pembelajaran menggunakan media kahoot!.

\section{Analisis Hasil Belajar Klasikal \\ a. Analisis Hasil Belajar di Kelas Eksperimen}

Tahap dalam pelaksanaan penelitian terdapat 3 tahap. Tahap pertama yaitu pretest dilakukan sebelum peserta didik mendapatkan treatment/perlakuan menggunakan media pembelajaran kahoot!. Tahap kedua yaitu pemberian treatment atau pemberian perlakuan. Tahap ketiga yaitu posttest dilakukan setelah peserta didik mendapatkan perlakuan menggunakan media pembelajaran kahoot!.

Berdasarkan lampiran hasil yang didapat dari pelaksanaan pretest, nilai tertinggi adalah 78,6 dan nilai terendah yaitu 28,6. Pada pelaksanaan pretest ini jumlah peserta didik yang berhasil mencapai batas tuntas mata pelajaran IPS atau KKM hanya berjumlah 1 orang dan yang tidak mencapai KKM ada 13 peserta didik dari 14 peserta didik. Sedangkan rata-rata yang didapatkan secara keseluruhan dari hasil pretest yaitu 45,4. Berdasarkan hasil yang diperoleh tersebut dapat disimpulkan bahwa masih banyak peserta didik yang masih mendapatkan nilai dibawah 75,00. Sedangkan pada tahap kedua yaitu pelaksanaan pembelajaran menggunakan media pembelajaran kahoot!, setelah pemberian perlakuan tersebut pada tahap ketiga yaitu pelaksanaan posttest, dalam pelaksanaan posttest nilai tertinggi yaitu 96,4 sedangkan nilai terendah adalah 71,4. Pada pelaksanaan pretest ini jumlah peserta didik yang berhasil mencapai batas tuntas mata pelajaran IPS atau KKM berjumlah 13 orang dan yang tidak mencapai KKM 1 orang. Sedangkan ratarata yang didapatkan secara keseluruhan dari hasil posttest yaitu 84,4 . Terdapat peningkatan yang signifikan dari hasil sebelumnya,

Berdasarkan hasil pretest dan posstest, nilai posttest lebih baik dibandingkan nilai pretest 
dengan nilai rata-rata posttest lebih tinggi yaitu sebesar 84,4 sedangkan nilai pretest sebesar 46,4. Berdasarkan segi ketuntasan belajar klasikal (ketuntasan peserta didik secara keseluruhan) ketuntasan klasikal yang diperoleh sebesar 92,8\% maka dapat ditarik kesimpulan bahwa secara keseluruhan hasil belajar kelas eksperimen sudah tuntas. Menurut Mulyasa (2004:99) dalam Mariani (2015:119) menyatakan bahwa suatu kelas disebut tuntas belajar apabila kelas tersebut telah mendapat sekurang-kurangnya $75 \%$ siswa telah tuntas belajar, sedangkan hasil penelitian menunjukkan terdapat 13 peserta didik yang tuntas atau dengan kata lain seluruh sampel peserta didik dikatakan tuntas dengan presentase $100 \%>75 \%$. Sehingga hasil penelitian dapat dikatakan tuntas secara klasikal (keseluruhan). Maka dapat juga dikatakan bahwa terdapat peningkatan yang signifikan antara pemahaman awal sebelum diberikan pembelajaran (hasil pretest) dan pemahaman akhir setelah diberikan pembelajaran (hasil posttest). Hal tersebut menunjukkan bahwa sub variable ketuntasan hasil belajar sudah efektif karena sudah mencapai indikator dalam penelitian yaitu mencapai nilai KKM dan ketuntasan belajar secara klasikal (75\% dari jumlah peserta didik) serta adanya peningkatan yang signifikan antara pemahaman awal dan pemahaman akhir peserta didik.

\section{b. Analisis Hasil Belajar di Kelas Kontrol}

Berdasarkan lampiran hasil yang didapat dari pelaksanaan pretest yaitu peserta didik mendapatkan nilai tertinggi yaitu 64,3 dan nilai terendah yaitu 21,4. Pada pelaksanaan pretest ini dari jumlah peserta didik 16 orang tidak ada yang tuntas dan berhasil mencapai KKM. Sedangkan rata-rata yang didapatkan secara keseluruhan dari hasil pretest yaitu 46,0. Berdasarkan hasil yang diperoleh tersebut dapat disimpulkan bahwa semua peserta didik mendapatkan nilai dibawah 75,00.

Tahap kedua yaitu pelaksanaan pembelajaran menggunakan media pembelajaran video animasi atau treatment. Setelah pemberian perlakuan tersebut, dilanjutkan pada tahap ketiga yaitu pelaksanaan posttest. Hasil dari posttest, didapat nilai tertinggi yaitu 92,9 sedangkan nilai terendah adalah 60,7. Pada pelaksanaan posttest ini dari 16 peserta didik yang berhasil mencapai batas tuntas mata pelajaran IPS atau KKM berjumlah 14 orang. Sedangkan rata-rata yang didapatkan secara keseluruhan dari hasil posttest yaitu 78,6. Terdapat peningkatan yang signifikan dari hasil sebelumnya. Dalam pelaksanaan posttest nilai rata-rata posttest lebih tinggi yaitu sebesar 78,6 sedangkan nilai pretest sebesar 46,0. Namun secara klasikal ketuntasan hasil belajar IPS kelas kontrol dengan pemberian media pembelajaran video animasi ketuntasan klasikal yang diperoleh sebesar 87,5\% maka dapat ditarik kesimpulan bahwa secara keseluruhan hasil belajar kelas kontrol juga tuntas.

Berdasarkan hasil belajar kelas eksperimen dan kontrol, masing-masing kelas mengalami perubahan hasil belajar. Hasil belajar dimasingmasing kelas mengalami perubahan yang baik dan hasil belajar meningkat. Hasil belajar di kelas eksperimen menunjukkan perubahan nilai dengan rata-rata pretest sebesar 46,4 dan ratarata posttest sebesar 84,4 . Kelas kontrol juga menunjukkan perubahan nilai dengan rata-rata pretest 46,0 dan rata-rata posttest sebesar 78,6.

Berdasarkan hasil uji beda data posttest diatas diketahui bahwa nilai sig.(2-tailed) yang dihasilkan sebesar 0,041. Karena 0,040 < 0,05 maka $H_{0}$ ditolak yang berarti bahwa rata-rata hasil belajar siswa yang diajar menggunakan media video animasi tidak sama dengan ratarata hasil belajar siswa yang diajar menggunakan media kahoot!, karena terdapat perbedaan rata-rata. Nilai rata-rata posttest kelas kontrol (8B) sebesar 78,6 dan kelas eksperimen (8C) sebesar 84,4. Karena rata-rata nilai posttest kelas eskperimen lebih besar dari rata-rata nilai kelas kontrol, sehingga dapat disimpulkan bahwa rata-rata hasil belajar siswa yang diajar menggunakan media kahoot! lebih tinggi daripada rata-rata hasil belajar siswa yang diajar menggunakan media video animasi.

Melalui perhitungan SPSS pada tabel Paired Sample Test menunjukkan nilai sig.(2-tailed) sebesar 0,000. Karena 0,000 $<0,05$, maka $H_{0}$ ditolak, artinya terdapat perbedaan yang signifikan rata-rata pretest dan posttest hasil belajar siswa kelas eksperimen dengan pemberian media pembelajaran kahoot!. Berdasarkan perhitungan tabel paired sample statistic, diketahui bahwa nilai rata-rata pretest sebesar 46,4 dan rata-rata posttest sebesar 84,4. Nilai rata-rata posttest lebih besar dari rata-rata pretest, sehingga dapat disimpulkan bahwa terdapat pengaruh media pembelajaran kahoot! terhadap hasil belajar siswa. 


\section{Respon Positif Peserta Didik Terhadap Pembelajaran}

a. Respon Positif Peserta Didik Terhadap Pembelajaran di Kelas Eksperimen

Jumlah peserta didik di kelas eksperimen adalah 14 orang. Terdapat 12 peserta didik dengan presentase $75 \%$ menanggapi atau memberikan respon sangat baik atau sangat setuju, sedangkan 2 peserta didik memberikan tanggapan baik atau setuju dengan presentase $12,50 \%$. Secara keseluruhan rata-rata peserta didik memberikan tanggapan sangat baik atau sangat setuju terhadap pembelajaran IPS menggunakan media pembelajaran kahoot!.

\section{b. Respon Positif Peserta Didik Terhadap Pembelajaran di Kelas Kontrol}

Jumlah peserta didik di kelas kontrol berjumlah 16 siswa. Terdapat 5 siswa memberikan respon setuju dengan presentase sebesar $31,25 \%$ dan 11 siswa lainnya dengan presentase sebesar $68,75 \%$ sangat setuju pada penggunaan media video animasi sebagai media pembelajaran IPS.

Media pembelajaran kahoot! mendapatkan respon yang positif dari peserta didik khususnya kelas VIII C di SMP Negeri 3 Tebo dikarenakan $70 \%$ lebih rata-rata peserta didik memberikan respon baik. Hal ini sejalan penelitian Tambun (2017:158) yang menyatakan bahwa respon peserta didik terhadap pembelajaran dikategorikan positif yaitu peserta didik merespon positif semua aspek berada diatas $70 \%$ pada angket respon peserta didik terhadap perangkat dan pelaksanaan pembelajaran.

Respon positif peserta didik dalam pembelajaran IPS untuk kelas eksperimen mendapat kriteria sangat aktif dengan jumlah $75 \%$ sedangkan untuk kelas kontrol mendapatkan jumlah 68,75\%. Sehingga respon positif peserta didik dalam pembelajaran IPS lebih efektif di kelas eksperimen (8C) dengan pembelajaran menggunakan media pembelajaran kahoot!.

\section{SIMPULAN}

Berdasarkan analisis pemahaman yang diperoleh dan beberapa faktor yang menjadi kendala pengembangan kompetensi, sekolah mengadakan berbagai

Pembelajaran IPS menggunakan media pembelajaran kahoot! lebih efektif dibandingkan dengan media pembelajaran video animasi. Pembelajaran menggunakan kahoot! lebih efektif ini berdasarkan ketercapaian guru dalam mengelola pembelajaran sangat baik, aktivitas peserta didik sangat aktif, memperbaiki hasil belajar secara klasikal, dan mampu mendapat respon positif dari peserta didik.

Penerapan media pembelajaran kahoot! pada mata pelajaran IPS materi interaksi anatarnegara-negara ASEAN sebaiknya mencoba semua fitur yang ada di dalam kahoot! tidak hanya fitur games saja, agar pembelajaran lebih bervariasi.

\section{DAFTAR PUSTAKA}

Abdul Munib, dkk. 2010. Pengantar Ilmu Pendidikan. Semarang: UNNES Press

Karmila, M. 2013. Meningkatkan Rasa Percaya Diri dalam Mengemukakan Pendapat Melalui Belajar Siswa Aktif (CBSA) dalam Pembelajaran IPS: Penelitian Tindakan Kelas di Kelas VIII K SMP Negeri 40 Bandung. Skripsi. Prodi Pendidikan Ilmu Pengetahuan Sosial Universitas Pendidikan Indonesia.

Kustandi, C \& Sutjipto, B. 2013. Media Pembelajaran. Bogor: Ghalia Indonesia.

Mulyasa. 2009. Menjadi Guru Profesional Menciptakan Pembelajaran Kreatif dan Menyenangkan. Bandung: PT Remaja Rosdakarya

Undang-Undang dan Peraturan Pemerintah

Undang-Undang Nomor 20 Tahun 2003 tentang Sistem Pendidikan Nasional (SISDIKNAS) pasal 